\title{
A one-compartment fructose/air biological fuel cell based on direct electron transfer
}

Xuee $\mathrm{Wu}^{\mathrm{a}^{*}}$ Feng Zhao ${ }^{\mathrm{a}}$, John R. Varcoe ${ }^{\mathrm{a}}$, Alfred E. Thumser ${ }^{\mathrm{b}}$, Claudio AvignoneRossa $^{c}$, Robert C.T. Slade ${ }^{a^{*}}$

${ }^{a}$ Chemical Sciences, ${ }^{b}$ Biological Sciences, ${ }^{c}$ Microbial Sciences,

University of Surrey, Guildford, GU2 7XH, United Kingdom

Corresponding authors:

Phone: (+44)1483682588, Fax: (+44)1483686851

E-mail:R.Slade@surrey.ac.uk; Xuee.wu@surrey.ac.uk 


\begin{abstract}
:
The construction and characterisation of a one-compartment fructose/air biological fuel cell (BFC) based on direct electron transfer is reported. The BFC employs bilirubin oxidase and D-fructose dehydrogenase adsorbed on a cellulose - multiwall nanotube (MWCNT) matrix, reconstituted with an ionic liquid route, as the biocathode and the bioanode for oxygen reduction and fructose oxidation reactions, respectively. The performance of the bioelectrode was investigated by chronoamperometric and cyclic voltammetric techniques in a standard three-electrode cell, and the polarization and long-term stability of the BFC was tested by potentiostatic discharge. An open circuit voltage of $663 \mathrm{mV}$ and a maximum power density of $126 \mu \mathrm{W} \mathrm{cm}{ }^{-2}$ were obtained in buffer at $\mathrm{pH}=5.0$. Using this regenerated cellulose-MWCNT matrix as the immobilization platform, this BFC has shown a relatively high performance and long-term stability compared with previous studies.
\end{abstract}

Keywords: Biological fuel cells; Fructose dehydrogenase; Billirubin oxidase; Cellulose; Direct electron transfer 


\section{Introduction}

Biological fuel cells (BFCs, including microbial and enzymatic fuel cells) and their potential uses have been attracting worldwide attention driven by the demands for clean and renewable energy resources; such devices directly convert chemical/biochemical energy into electrical energy (Bullen et al. 2006; Davis et al. 2007). Compared to conventional fuel cells, BFCs produce lower power density, but they have the potential of carrying out specific tasks such as the powering of implantable medical devices by enzymatic fuel cells (Barton, et al., 2004; Minteer et al., 2007) or different wastewater treatment by microbial fuel cells (Zhao et al., 2008, 2009a).

Enzymatic fuel cells can be divided into mediated electron transfer (MET) and direct electron transfer (DET) types, which are the focus of most current research (Barton, et al., 2004; Bullen et al. 2006). In MET-type systems, redox chemicals are added as mediators to enhance electron transfer processes; these mediators are, however, often toxic and present potential environmental problems; they also lead to voltage loss as there is a potential difference between the active site of enzymes and mediators. The DET-type BFCs, where a direct electron exchange between the active site of the enzyme and the electrode, possess very important advantages due to their simple construction allowing one compartment membraneless BFCs, which has the potential benefit of miniaturisation and low cost. The main drawback associated with DET is that this process is usually prohibited by the enzyme structure. A variety of 
attempts have been made to improve the electronic communication between the active site of enzyme and the electrode surface (Degani and Heller, 1989; Ghindilis, et al., 1997; Ramanavicius et al., 2005, Sarma et al. 2009). However, there are only a few reported BFCs based on membraneless DET-type biocatalysts for both the cathode and anode reactions (Ramanavicius et al., 2005, 2008; Coman, et al., 2008; Vincent, et al., 2005; Kamitaka, et al., 2007a; Tasca, et al., 2008). The long-term stability is a key aspect of BFCs (Kim et al., 2006) and previously reported BFCs based on DET show relatively poor long-term stability.

Natural polymers provide unique characteristics for enzyme immobilization due to their abundance and especially the apparent biocompatibility which could minimize the possibilities of enzyme denaturation. Cellulose is the most abundant and renewable biopolymer on earth, has many advantages when used as an enzyme immobilization material, and provides a biocompatible environment to enhance the stabilization of immobilized proteins. The challenge to using cellulose as a material for enzyme immobilization is its insolubility in common solvents due to its high crystallinity. Some recent studies have showed that room temperature ionic liquids (RTILs), as environmental friendly solvents, can exhibit good dissolution power for cellulose, which can then be reconstituted into a variety of forms (Kosan, et al., 2008; Hermanutz, et al., 2008; Wu, et al., 2009).

Carbon nanotubes (CNTs) represent an important group of nanomaterials with attractive geometrical, electronic and chemical properties (Katz and Willner, 2004; Zhou et al., 2009). The unique properties of carbon nanotubes make them attractive for the development of bioelectrochemical devices. 
We demonstrate here a membraneless fructose/air BFC, using commercially available D-fructose dehydrogenase (FDH) and bilirubin oxidase (BOD) absorbed on the surface of electrodes modified with cellulose-MWCNT matrix, which is regenerated by RTIL, as bioanode and biocathode for D-fructose oxidation and oxygen reduction reactions, respectively. The long term stability of the assembled BFC under continuous operation is also presented.

\section{Experimental section}

\subsection{Chemicals and reagents}

Bilirubin oxidase (BOD; EC 1.3.3.5) from Myrothecium verrucaria and D-Fructose Dehydrogenase (FDH; EC 1.1.99.11) from Gluconobacter industrius, microcrystalline cellulose and the ionic liquid 1-ethyl-3-methylimidazolium acetate ([EMIM] $\left[\mathrm{CH}_{3} \mathrm{COO}\right]$ ) were purchased from Sigma-Aldrich and used with no further purification. Multiwall carbon nanotubes (Nanocyl-3100 series with an average diameter of $10 \mathrm{~nm}$ ) were treated as described previously (Liu et al., 1998). All other chemicals used in this study were of analytical grade. All solutions were prepared with ultra-pure water $\left(>18.2 \mathrm{M} \Omega \mathrm{cm}^{-1}\right)$ from a purite purification system.

\subsection{Preparation of the modified anode and cathode}

The glassy carbon (GC) electrodes were polished successively with 0.3 and $0.05 \mu \mathrm{m}$ alumina slurries, and then sonicated in ultra-pure water. The cellulose-MWCNT 
modified GC electrodes were prepared as follows: the cellulose-[EMIM][ $\left.\mathrm{CH}_{3} \mathrm{COO}\right]$ solution was obtained by thoroughly mixing cellulose $(3.0 \%$ mass $)$ and [EMIM] $\left[\mathrm{CH}_{3} \mathrm{COO}\right]$, heating up to $70^{\circ} \mathrm{C}$ for $1 \mathrm{~h}$ in an ultrasonic bath until an optically clear solution was obtained. The MWCNT (3.0\% mass) were then suspended in [EMIM] $\left[\mathrm{CH}_{3} \mathrm{COO}\right]$-cellulose solution by grinding in an agate mortar for 15 min under high purity nitrogen to prevent the $[\mathrm{EMIM}]\left[\mathrm{CH}_{3} \mathrm{COO}\right]$ from absorbing moisture. The resulting materials were evenly spread on the GC surface using a doctor blade and the modified electrode was then immersed in ultra-pure water, to remove the $[\mathrm{EMIM}][\mathrm{CH} 3 \mathrm{COO}]$ by dissolution, leaving the cellulose-MWCNT matrix on the electrode surface.

Bioelectrodes were prepared by placing an aliquot of $0.01 \mathrm{~cm}^{3}$ of enzyme solution (i.e. $~ 0.1 \mathrm{mg}$ of BOD for cathode or of FDH for anode) on the electrode surface, and allowing the solution to dry at the surface of the electrode in air at $22^{\circ} \mathrm{C}$. The electrodes were rinsed with deionized water to remove weakly adsorbed enzymes before electrochemical measurements. When not in use, the bioelectrodes were stored dry at $4^{\circ} \mathrm{C}$.

\subsection{Bioanode and biocathode electrochemical measurements}

Chronoamperometric and cyclic voltammetric measurements were carried out by using a computer-controlled Autolab potentiostat/galvanostat (EcoChemie, Netherlands) in a three-electrode cell with a $25 \mathrm{~cm}^{3}$ volume and consisting of working electrode, a Pt wire counter electrode and an $\mathrm{Ag} / \mathrm{AgCl}$ reference electrode (BASi, 3.0 mol dm ${ }^{-3} \mathrm{NaCl},+0.196 \mathrm{~V}$ vs. SHE at $298.2 \mathrm{~K}$ ). Control experiments using unmodified 
GC and enzyme-free cellulose-MWCNT coated electrodes were carried out. The electrolyte was $0.2 \mathrm{~mol} \mathrm{dm}^{-3}$ citrate buffer, which was purged with high purity nitrogen (BOC UK) or air (air pump) for at least 15 min prior to experiments to obtain a nitrogen- or air-saturated solution, respectively.

\subsection{Biological fuel cell measurement}

The FDH anode, $\mathrm{BOD}$ cathode and $\mathrm{Ag} / \mathrm{AgCl}$ reference electrode were placed in a one-compartment configuration (see the S-Fig. 1 in supporting information). The biological fuel cell was operated in citrate buffer $(\mathrm{pH}=5.0)$ containing $200 \mathrm{mmol} \mathrm{dm}^{-3}$ D-fructose under continuous air-bubbling conditions (using an air pump). The potentiostatic discharge polarization performances and the durability behavior at constant voltage of $0.35 \mathrm{~V}$ were measured using a Fuel Cell Test System (Arbin Instrument Corp.). The current density and power density were calculated based on the geometrical surface area of the electrode. The potentials of the cathode and the anode versus $\mathrm{Ag} / \mathrm{AgCl}$ as a function of time were individually recorded using a digital multimeter (Integra 2700 series equipped with 7700 multiplexer, Keithley Instruments Inc.) interfaced to a personal computer for data collection (Zhao et al., 2009a, 2009b). The internal ohmic resistance of the BFCs was determined by electrochemical impedance spectroscopy using a Solartron Analytical 1260 frequency response analyzer operating in conjunction with a Solartron Analytical 1287 potentiostat/galvanostat in the frequency range $1 \mathrm{MHz}-0.1 \mathrm{~Hz}$ and with a potential perturbation signal of $10 \mathrm{mV}$ rms (Zhao et al., 2009b). All electrochemical experiments and BFC operations were carried out at $22.0 \pm 1.0^{\circ} \mathrm{C}$. 


\section{Results and Discussion}

\subsection{The electrocatalytic behavior of the FDH anode}

D-fructose dehydrogenase is a membrane-bound enzyme with a molecular weight of ca. $140 \mathrm{kDa}$ and contains flavin and heme c as prosthetic groups (Ameyama, et al., 1981). This enzyme shows high substrate specificity for D-fructose and can catalyze the oxidation of D-fructose to 2-keto-D-fructose, which is therefore used extensively in food and clinical analyse (Matsumoto, et al., 1986; Nakashima, et al., 1985). In this study, the electrocatalytic activity of FDH towards D-fructose was investigated by chronoamperometry in a standard three-electrode electrochemical cell. In the absence of D-fructose (i.e. $0-140 \mathrm{~s}$ ), the measured current density levels were around $30 \mu \mathrm{A}$ $\mathrm{cm}^{-2}$ (Fig. 1a). A significant increase in current was obtained when $0.5 \mathrm{mmol} \mathrm{dm}{ }^{-3} \mathrm{D}$ fructose was added into the buffer, and a maximum stable current density of $280 \mu \mathrm{A}$ $\mathrm{cm}^{-2}$ was achieved by the direct electron transfer between the enzyme and the electrode. Control experiments were performed on a blank glassy carbon and enzymefree cellulose-MWCNT modified electrode; no current change was observed when fructose was added in solution (data not shown). Oxygen had no effect on the electrocatalytic reaction of the FDH anode since no observable current change was obtained when air purged the buffer during $360-500 \mathrm{~s}$.

Fig. $1 \mathrm{~b}$ shows the current as a function of $\mathrm{D}$-fructose concentrations. The current increased significantly to $892 \mu \mathrm{A} \mathrm{cm}^{-2}$ when the concentration of D-fructose reached 
$15.0 \mathrm{mmol} \mathrm{dm}{ }^{-3}$. This relationship between the current change and the concentration can offer advantages for the development of a D-fructose biosensor. A plateau response was observed at high $\mathrm{D}$-fructose concentration, indicating a characteristic Michaelis-Menten kinetics mechanism. The apparent Michaelis-Menten constant $\mathrm{K}_{\mathrm{m}}$, which relates to an enzyme's affinity for a substrate, for D-fructose is $2.3 \mathrm{mmol} \mathrm{dm}$ and is smaller than the reported values $11 \pm 1 \mathrm{mmol} \mathrm{dm}^{-3}$ (Tominaga, et al., 2009) and 9-10 mmol dm${ }^{-3}$ (Ameyama, et al., 1981; Kamitaka, et al., 2007b), suggesting that the FDH in this study has higher affinity for D-fructose.

The dependence of the electrooxidation activity on $\mathrm{pH}$ for the FDH electrode was evaluated by holding potential at $+0.3 \mathrm{~V}$ versus $\mathrm{Ag} / \mathrm{AgCl}$ in the presence of $5.0 \mathrm{mmol}$ $\mathrm{dm}^{-3} \mathrm{D}$-fructose as substrate. It was found that the bioelectrode retained a relatively high activity in the $\mathrm{pH}$ range $4.0-7.0$, and the optimum $\mathrm{pH}$ value (i.e. maximum current density) is around $\mathrm{pH} 5$, as shown in Fig. 2.

\subsection{Oxygen reduction reaction on the BOD cathode}

Multicopper oxidases, such as bilirubin oxidase (BOD), are able to catalyze a fourelectron reduction reaction of dioxygen to water, and are promising enzymes as biocatalysts for the BFC cathodic reaction. Fig. 3 shows cyclic voltammograms for the BOD electrode under anaerobic and under air-purging conditions, which gave a clear oxygen reduction reaction wave in the presence of oxygen in the buffer. The addition of $\mathrm{D}$-fructose did not produce a recordable current response at the BOD modified electrode (data not shown). The "ideal" oxygen reduction potential at room temperature and neutral $\mathrm{pH}$ is $0.61 \mathrm{~V}$ vs. $\mathrm{Ag} / \mathrm{AgCl}$; however, values are always $0.2 \sim$ 
$0.3 \mathrm{~V}$ lower than the theoretical value when platinum, porphyrins and phthalocyanines are used as catalysts for oxygen reduction reaction (Zhao et al, 2009a). For BOD as biocatalyst at $\mathrm{pH}=5.0$, Fig. 3 shows that the current of oxygen reduction reaction can be observed at $0.63 \mathrm{~V}$, which is closer to the ideal potential value than that for the inorganic catalysts and demonstrates a potential for high performance for cathodic reaction.

Fig. 2 shows the $\mathrm{pH}$ dependence of the BOD-catalyzed oxygen reduction activity (i.e. electrode current). The BOD activity is relatively low at $\mathrm{pH} 3.0$ and 8.0, reaches a maximum value at $\mathrm{pH} 4.0$, and a relatively high activity persists at $\mathrm{pH}$ 7.0. The $\mathrm{pH}$ variation demonstrates that the optimal $\mathrm{pH}$ range of the immobilized $\mathrm{BOD}$ is broader than that of the free protein in solution (Otsuka, et al., 2007). In this study, buffer at $\mathrm{pH} 5.0$ was used in the BFC operation in order to obtain high power generation (the FDH modified anode showed the maximum activity at this $\mathrm{pH}$ ).

\subsection{BFC potentiostatic discharge performance}

A one-compartment mediatorless D-fructose/air BFC was constructed using FDH and BOD absorbed on reconstituted cellulose-MWCNT matrix modified electrodes as bioanode and biocathode, respectively. In order to ensure that D-fructose concentration is sufficient in long-term BFC discharge operation, $200 \mathrm{mmol} \mathrm{dm}{ }^{-3} \mathrm{D}-$ fructose was added to the compartment at beginning of the test.

The cell voltage of a BFC can be expressed in terms of the overpotentials associated with different fundamental phenomena as shown in the following equations:

$$
E_{\text {cell }}=E_{c}-E_{a}-\eta_{\text {act }}-\eta_{\text {conc }}-\eta_{\text {ohm }} \quad \text { Equation (1) }
$$


where $E_{c}$ and $E_{a}$ are the open circuit potentials for the cathodic and anodic reactions respectively; $\eta_{\text {act }}, \eta_{\text {conc }}$ and $\eta_{\text {ohm }}$ are the charge transfer overpotential; the mass transport overpotential and the ohmic overpotential of BFCs, respectively. In a polarization curve, the region of charge transfer overpotential is located at low currents where the reactants are abundant and the current is small enough that the ohmic and mass transfer overpotential is negligible; mass transfer overpotential is prevalent at relatively high current densities when the reactants cannot be supplied to the electrode reaction zones at the rate required to sustain the generation current. Ohmic overpotential is, in general, at intermediate currents in the polarization curve. It should be noted that these different current range are generally located with varying and significant levels of overlap for biofuel cells.

In the majority of BFC studies to date, discharge (polarization) performance curves have been measured by connecting different external resistors between the electrodes and measuring the resulting currents and voltages; however, the use of constant absolute resistances does not always yield useful information, especially when BFCs with different configurations and dimensions are being compared. Constant current and potential based performance measurement techniques are used as standard in the development of chemical fuel cells, while the effect of a changing load on a practical fuel cell system is normally evaluated using simulated discharge current/potential profiles. The data of constant potential/current are more useful when BFCs are designed as power supplies for practical systems (Zhao et al., 2009b). In this work, the discharge performance curve was measured using a potentiostatic discharge, where the voltage is controlled (i.e. power is supplied to the fuel cell tester from the BFC being 
studied) and the resulting currents are measured. Fig. 4a shows the potential control profile and resulting current outputs with time, where an equilibration time of 60 seconds was used before recording each data point. Steady state conditions are easily achieved at the beginning of testing, with low current densities because the main performance limitations are electrokinetic (the region of predominant charge transfer overpotentials). In the high current range, the equilibration is clearly less rapid due to the added involvement of mass transport limitations (impedances with longer time constants). The internal ohmic resistance of the BFC was $92.6 \mathrm{ohm}$, measured as the high-frequency resistance in impedance spectroscopic data. A closer distance between the anode and the cathode will reduce the internal ohmic resistance, but would not be helpful for reducing voltage losses (less than $0.006 \mathrm{~V}$ due to the low current) in the present case.

Fig. $4 \mathrm{~b}$ shows the potentials of the individual FDH anode and BOD cathode during the BFC discharge testing. The open circuit voltage of BFC was $663 \mathrm{mV}$ (Fig. 4c), where the open circuit potentials of FDH bioanode and BOD biocathode were 635 and $-28 \mathrm{mV}$ vs. $\mathrm{Ag} / \mathrm{AgCl}$, respectively. The biocathode potential shifted to less positive values and bioanode potential shifted to more positive values as expected with increased current. In the low current region (see Fig. $4 \mathrm{a}$ and $4 \mathrm{~b}$ ), the potential change of the cathode is almost two times larger compared to that for the anode; this suggests that the anode is kinetically limiting under the operational conditions. However, in the high current region, the overall potential shifts of the biocathode and bioanode at $800 \mathrm{~s}$ are $387 \mathrm{mV}$ and $276 \mathrm{mV}$, respectively. The potential change of anode and cathode suggests that performance limitations of the BOD cathode are predominantly due to 
limitation of the mass transfer of oxygen. This cell exhibited a maximum current density $577 \mu \mathrm{A} \mathrm{cm}^{-2}$ and a maximum output power density of $126 \mu \mathrm{W} \mathrm{cm}{ }^{-2}$, which is a relatively high performance compared to most one-chamber BFC based on direct electron transfer (see Table 1 in the supporting information). It certainly needs to be noted that the BFC conditions discussed in the current study were not optimized for providing the highest possible performance. A high-efficiency BFC configuration and operation conditions could yield a high-performance BFC, which could be enhanced by the following: 1) increasing enzyme loading to decrease charge transfer resistances; 2) stirring the electrolyte or optimising the cell configuration to reduce mass transfer resistance; 3) utilising an optimal temperature for high electrochemical activity of the enzyme; 4) replacing air by pure oxygen to increase the BFC voltage and power output. Due to low current, the ohmic voltage loss is considered an "acceptable loss" in the present case, but, it will become parasitic when current is enhanced or the device is scaled up.

\subsection{The stability of BFC and bioelectrodes}

Based on polarization tests, a potential of $0.35 \mathrm{~V}$ was chosen to investigate the potentiostatic discharge performance stability of BFC as a function of time. The BFC showed $90 \%$ of the initial power (or current) after $12 \mathrm{~h}$ discharge and $52 \%$ of the initial power after 87 hours of continuous operation (Fig. 5a). There are several factors that affect electrode stability during long term operation: enzyme activity, amount of enzyme on the electrode surface (leaching problem) and fuel concentration. In the current studies, the decrease of enzyme electrocatalytic activity as a function of time is 
the primary reason for the change in electrode performance. The decrease in power generation suggests that the performance of either a single electrode or of both anode and cathode decreases. In order to determine the limiting factor, the potential shifts of the bioanode and the biocathode with time were recorded during continuous operation of the BFC. Fig. 5b shows that both the bioanode and the biocathode potentials shift towards negative values. The cathode potential shifts away from its open circuit potential; this should produce higher current with a stable cathode, but the data show that current decreases with time (Fig. 5a). The decreasing current shifts the anodic potential towards its open circuit potential. This indicates that the long-term performance of the BFC is restricted by the stability of the BOD cathode; otherwise, the anode potentials would shift to more positive values.

The long term stability of individual bioelectrodes was also studied in a threeelectrode system, as shown in Fig. 6. After continuous operation for $45 \mathrm{~h}$ at a constant potential, the FDH anode and BOD cathode yielded 80 and $60 \%$ of the initial current density values respectively. After $160 \mathrm{~h}$ continuous operation, the FDH bioelectrode was still yielding $70 \%$ of the initial current density (data not shown). The long-term storage stability of the individual bioelectrode was also determined; it was found that after 40 days storage at $4^{\circ} \mathrm{C}$, the bioanode still obtained $93 \%$ of the initial current density, but the biocathode lost almost 50\%. These results corroborate BFC stability tests above and confirm the performance loss is predominantly due to the BOD cathode.

The results showed that the BFC based on simple physically adsorption of the enzymes on cellulose-MWCNT matrix is more stable than previously reported 
DET-type BFCs, in which the power decreased down to half of the initial value after continuous operation (Table 1, supporting information) (Ramanavicius et al., 2005; Coman, et al., 2008; Vincent, et al., 2005, Kamitaka, et al., 2007; Tasca, et al., 2008). The stability can be attributed to the hydrophilic properties of the cellulose-MWCNT matrix, which can provide a biocompatible microenvironment to retain enzyme activity. Also, the abundant hydroxyl groups in cellulose enable formation of hydrogen bonds with adsorbed enzyme molecules which will hinder leaching.

\section{Conclusions}

We have successfully developed a simple application of a one compartment (membraneless) and mediatorless D-fructose/air biological fuel cell, which yields a maximum power of about $126 \mu \mathrm{W} \mathrm{cm} \mathrm{cm}^{-2}$ measured by potentiostatic discharge techniques. Anode kinetics limits BFC performance in the low current region; but mass transfer resistance (especially for oxygen diffusion) is predominant in this high current region. Biocathode stability is predominant in the performance loss in long term operation. This study shows that cellulose-MWCNT based matrix provides a promising platform for enzyme immobilization and offers a new route to the development of BFCs with relative high performance and long term stability. 


\section{Acknowledgements}

This research was supported by the Engineering and Physical Sciences Research Council as part of the UK's Supergen5 Biological Fuel Cells Consortium programme (EPSRC contract: EP/D047943/1). We thank Prof. Fraser Armstrong's research group in the Inorganic Chemistry Laboratory at the University of Oxford for expert input in enzyme immobilisation. 


\section{References}

Ameyama, M., Shinagawa, E., Matsushita, K., Adachi, O., 1981, J. Bacteriol. 145, 814-823.

Barton, S.C., Gallaway, J., Atanassov, P., 2004, Chem. Rev., 104, 4867-4886.

Bennetto, H.P., Stirling, J., Delaney, G., Roller, S., Thurston, C.S., Mason, J.R., 1983, Process Biochem. 18, R17

Bullen, R.A., Arnot, T.C., Lakeman, J.B., Walsh, F.C., 2006, Biosens. Bioelectron. $21,2015-2045$.

Coman,V., Vaz-Dominguez, C., Ludwig, R., Herreither, W., Haltrich, D., De Lacey, A.L., Ruzgas, T., Gorton, L., Shleev, S., 2008, Phys. Chem. Chem. Phys. 10, 60936096.

Davis, F., Higson, S.P.J., 2007, Biosens. Bioelectron. 22, 1224-1235.

Degani,Y., Heller, A., 1989, J. Am. Chem. Soc. 111, 2357-2358.

Ghindilis, A.L., Atanasov, P., Wilkins, E., 1997, Electroanal. 9, 661-674.

Hermanutz, F., Gaehr, F., Uerdingen, E., Meister, F., Kosan, B., 2008, Macromol. Symp. 262, 23-27.

Kamitaka, Y., Tsujimura, S., Kano, K., 2007a, Chem. Lett. 36, 218-219.

Kamitaka, Y., Tsujimura, S., Setoyama, N., Kajino, T., Kano, K., 2007b, Phys. Chem. Chem. Phys. 9, 1793-1801.

Katz, E., Willner, I., 2004, Chem. Phys. Chem. 5, 1085-1104.

Kim, J., Jia, H.F., Wang, P., 2006, Biotechnol. Adv. 24, 296-308.

Kosan, B., Michels, C., Meister, F., 2008, Cellulose 15, 59-66. 
Liu, J., Rinzler, A.G., Dai, H. J., Hafner, J.H., Bradley, R.K., Boul, P.J., Lu, A., Iverson, T., Shelimov, K., Huffman, C.B., Rodriguez-Macias, F., Shon, Y.S., Lee, T.R., Colbert, D.T., Smalley, R.E., 1998, Science 280, 1253-1256.

Matsumoto, K., Hamada, O., Ukeda, H., Osajima, Y., Anal. Chem. 1986, 58, $2732-$ 2734.

Minteer, S.D., Liaw, B.Y., Cooney, M. J., 2007, Curr. Opin. Biotechnol. 18, 228234.

Nakashima, K., Takei, H., Adachi, O., Shinagawa, E., Ameyama, M., 1985, Clin. Chim. Acta 151, 307-310.

Otsuka, K., Sugihara, T., Tsujino, Y., Osakai, T., Tamiya, E., 2007, Anal. Biochem. 370, 98-106.

Ramanavicius, A., Kausaite, A., Ramanaviciene, A., 2005, Biosens. Bioelectron. 20, 1962-1967.

Ramanavicius, A., Kausaite, A., Ramanaviciene, A., 2008, Biosens. Bioelectron. 24, 761-766.

Tasca, F., Gorton, L., Harreither, W., Haltrich, D., Ludwig, R., Noll, G., 2008, J. Phys. Chem. C 112, 9956-9961.

Tominaga, M., Nomura, S., Taniguchi, I., 2009, Biosens. Bioelectron. 24, 11841188.

Vincent, K. A., Cracknell, J.A., Lenz, O., Zebger, I., Friedrich B., Armstrong, F.A., 2005, Proc. Nat. Acad. Sci. USA 102, 16951-16954.

Sarma, A.K., Vatsyayan, P., Goswami, P., Minteer, S.D., 2009, Biosens. Bioelectron. 24, 2313-2322. 
Wu, X., Zhao, F., Varcoe, J.R., Thumser, A.E., Avignone-Rossa, C., Slade, R.C.T., 2009, Bioelectrochem. Doi: 10.1016/j.bioelechem.2009.05.008.

Zhao, F., Rahunen, N., Varcoe, J.R., Chandra, A., Avignone-Rossa, C., Thumser, A.E., Slade, R.C.T., 2008. Environ. Sci. Technol. 42 (13), 4971-4976.

Zhao, F., Rahunen, N., Varcoe, J.R., Roberts, A.J., A., Avignone-Rossa, C., Thumser, A.E., Slade, R.C.T., 2009a, Biosens. Bioelectron. 24, 1391-1396.

Zhao, F., Slade, R.C.T., Varcoe, J.R., 2009b, Chem. Soc. Rev. 38, 1926-1939.

Zhou, M., Deng, L., Wen, D., Shang, L., Jin, L.H., Dong, S.J. 2009, Biosens. Bioelectron. Doi:10.1016/j.bios.2009.02.028 


\section{Captions}

Fig. 1. a) Chronoamperometric response of a FDH modified electrode held at a potential of $0.30 \mathrm{~V}$ vs. $\mathrm{Ag} / \mathrm{AgCl}$ in $0.2 \mathrm{~mol} \mathrm{dm}^{-3}$ buffer at $\mathrm{pH} 5.0$. D-fructose of 0.5 mmol dm${ }^{-3}$ was added in the buffer at $140 \mathrm{~s}$, and continuous air supply was started at 360 s. b) Catalytic current density as a function of D-fructose concentration in air purged buffer at a potential of $0.30 \mathrm{~V}$ vs. $\mathrm{Ag} / \mathrm{AgCl}$. The relative standard deviation (R.S.D.) is $3.0 \%$.

Fig. 2. $\mathrm{pH}$ dependence on the relative activity (catalytic currents) obtained from FDH (O)and BOD ( ) absorbed on cellulose-MWCNT matrix modified electrode in 0.2 mol dm ${ }^{-3}$ buffer under air saturation in the presence of $200 \mathrm{mmol} \mathrm{dm}^{-3} \mathrm{D}$-fructose. The bioelectrodes were held at a potential of $0.3 \mathrm{~V}$ and $0.2 \mathrm{~V}$ versus $\mathrm{Ag} / \mathrm{AgCl}$, respectively.

Fig. 3. Cyclic voltammograms of the BOD electrode in buffer at $\mathrm{pH}=5.0$ under airpurging (dashed line) or anaerobic (solid line) conditions. Scan rate $10 \mathrm{mV} \mathrm{s}^{-1}$.

Fig. 4. a) Variable current density via controlled voltages of the BFC in potentiostatic discharge measurement. b) The potentials of the anode and the cathode as a function of time during the potentiostatic discharge measurements of the BFC. c) The polarisations $(\bigcirc)$ and power density $(O)$ curves of a one-compartment biological fuel cell with FDH anode and BOD cathode. The error bars are for $n=3$ repeated tests; the relative standard deviation (R.S.D.) is $3.5 \%$. 
Fig. 5. a) The stability of the one compartment fructose/air BFC in D-fructose solution $\left(0.2 \mathrm{~mol} \mathrm{dm}{ }^{-3}, \mathrm{pH}=5.0\right)$ under continuous air supply. $P_{o}$ represents the maximum power density of the BFC and $P$ is the power density recorded at different times. b) Potential changes of the FDH anode and the BOD cathode during the continuous discharge of the BFC at a constant voltage of $0.35 \mathrm{~V}$.

Fig. 6. The current stability at the FDH and BOD modified electrodes as a function of time in buffer containing $200 \mathrm{mmol} \mathrm{dm}{ }^{-3} \mathrm{D}$-fructose under air purging conditions. The applied potentials were $0.30 \mathrm{~V}$ and $0.20 \mathrm{~V}$ vs. $\mathrm{Ag} / \mathrm{AgCl}$ for the $\mathrm{FDH}-$ and BODmodified electrodes respectively. 

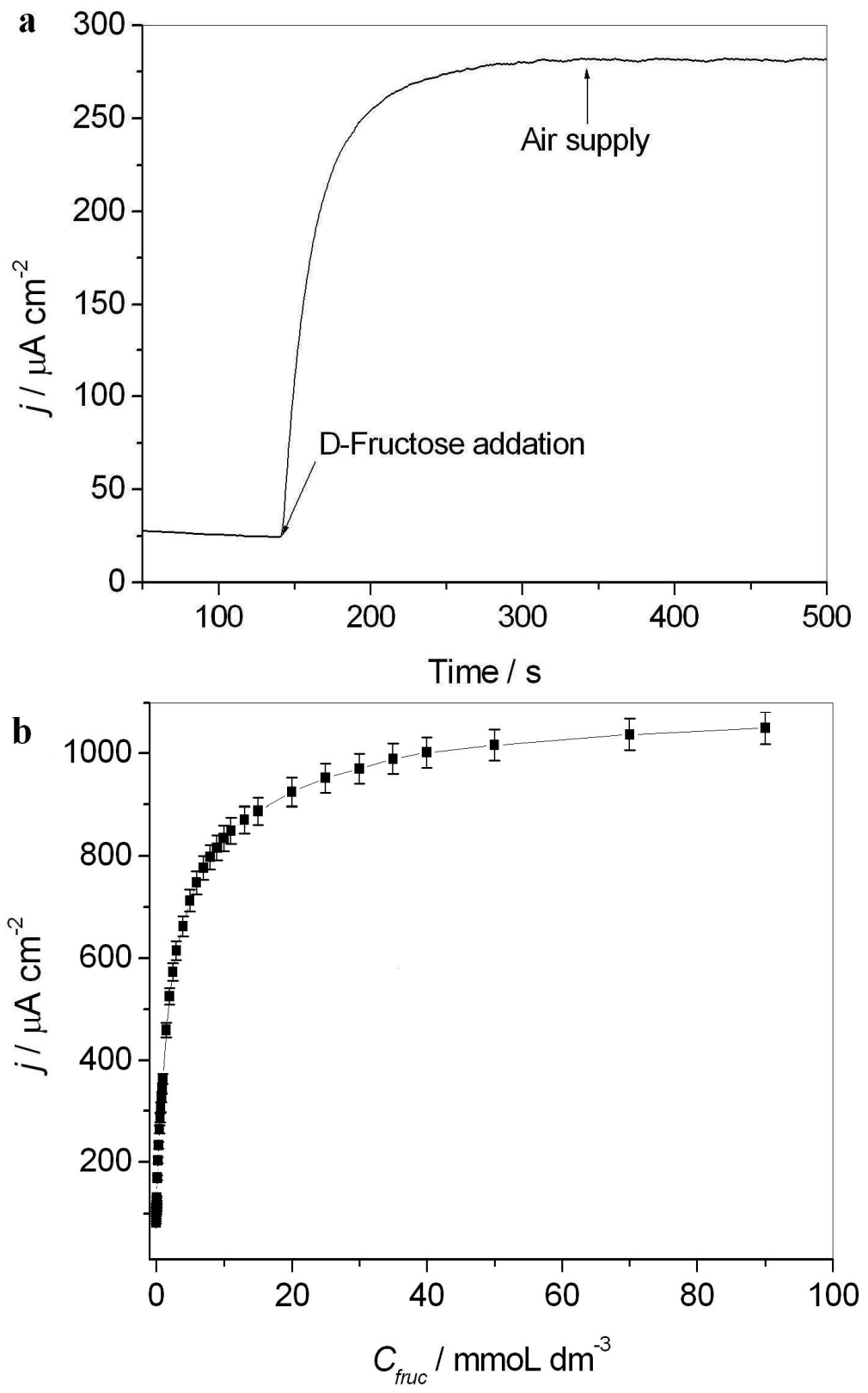

Figure_1 


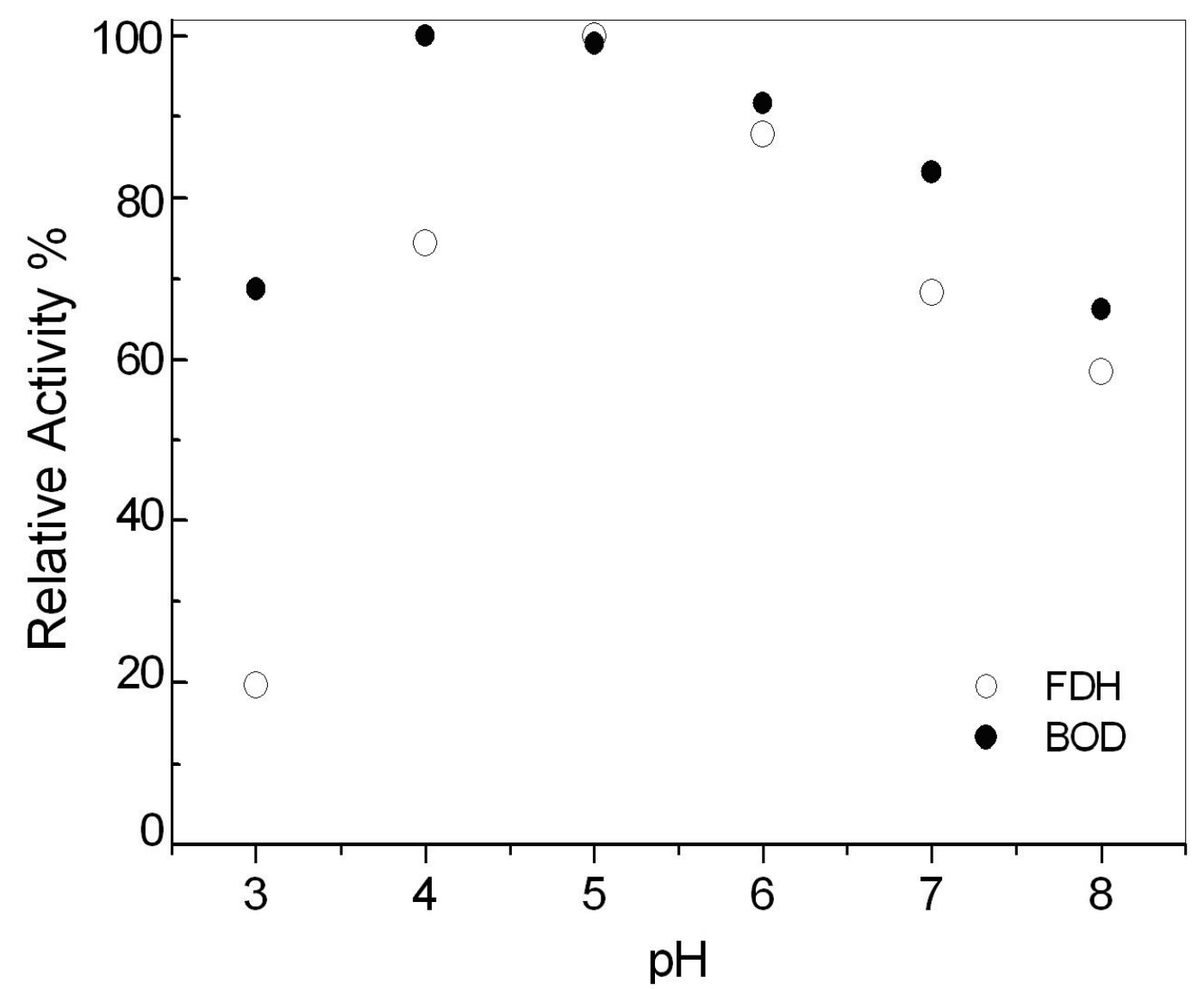

Figure_2 


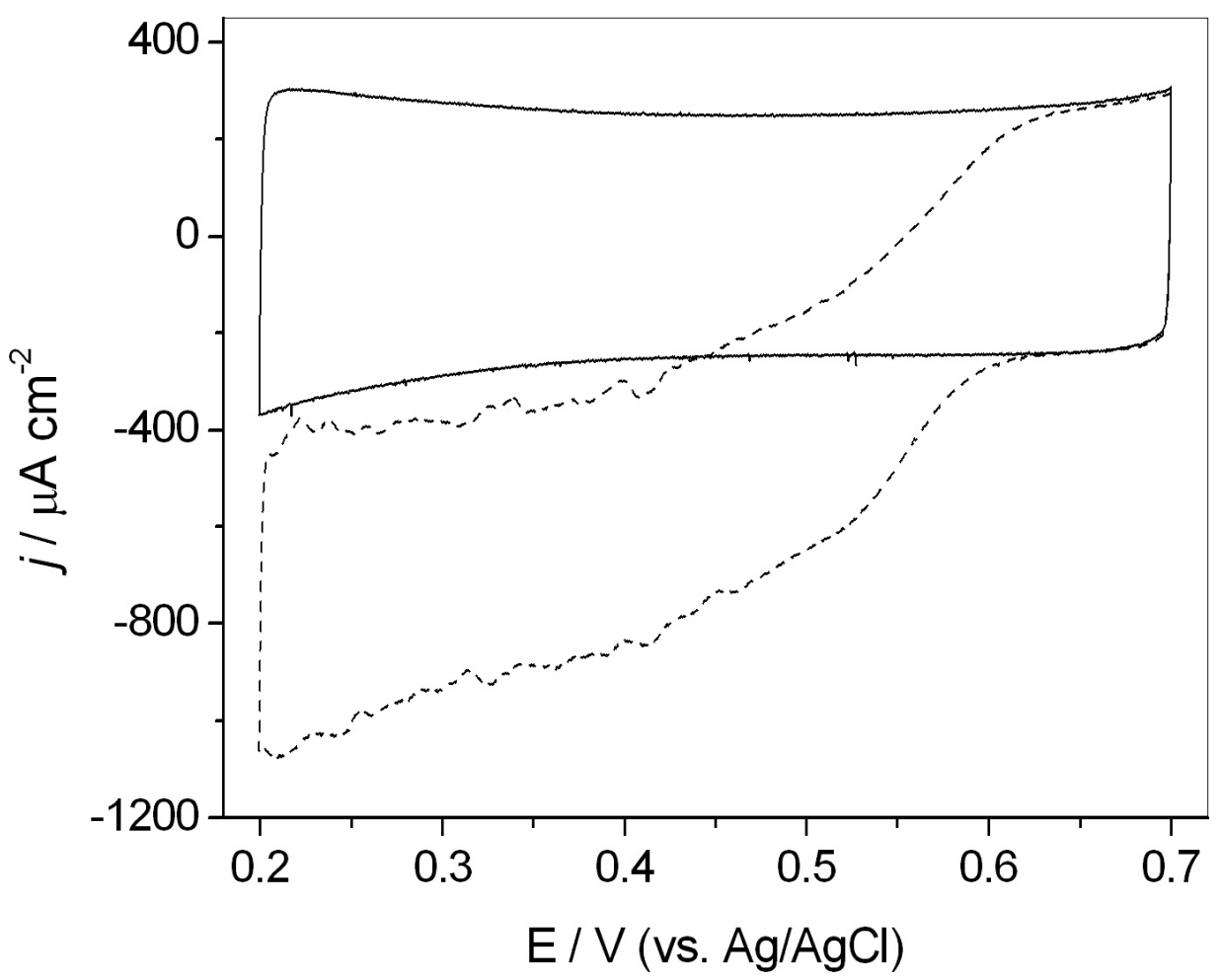

Figure_3 

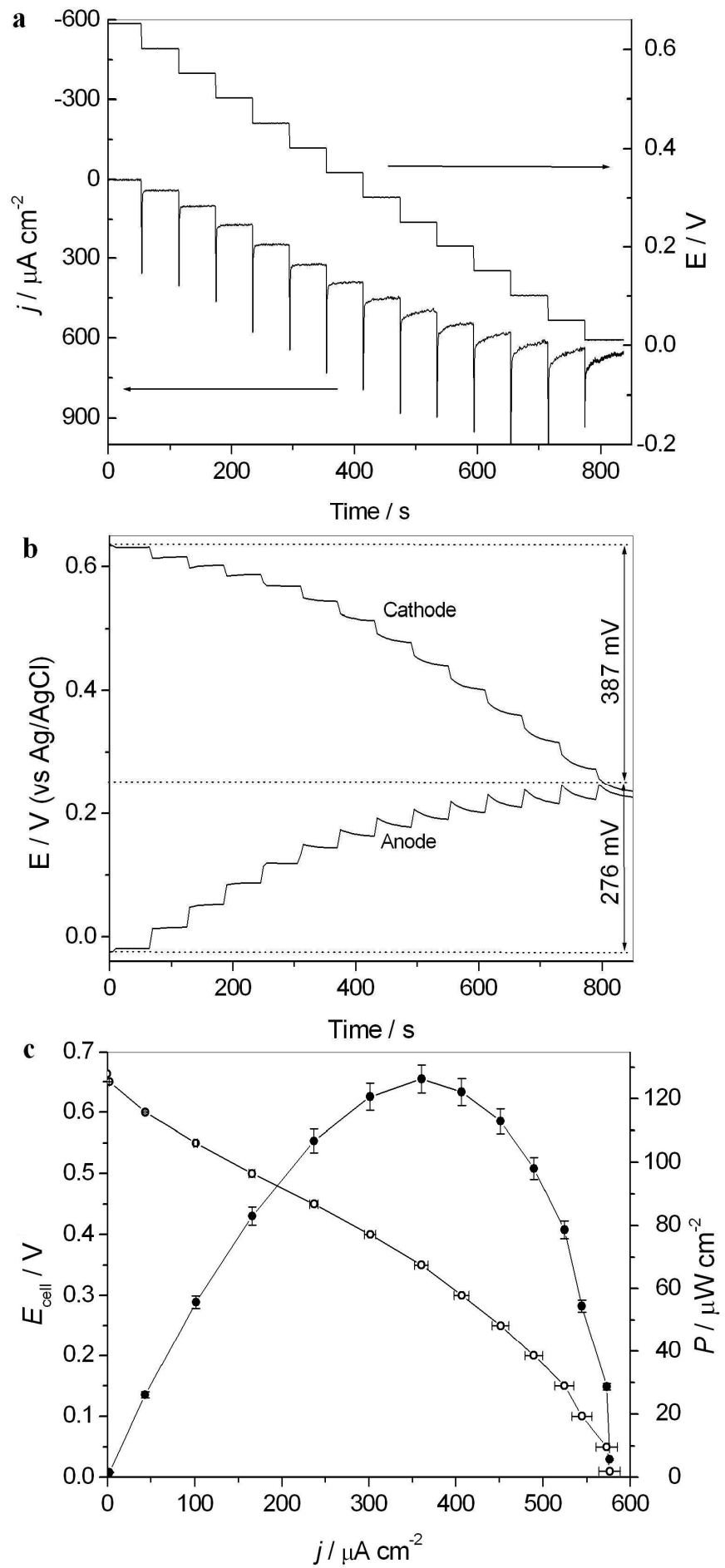

Figure_4 


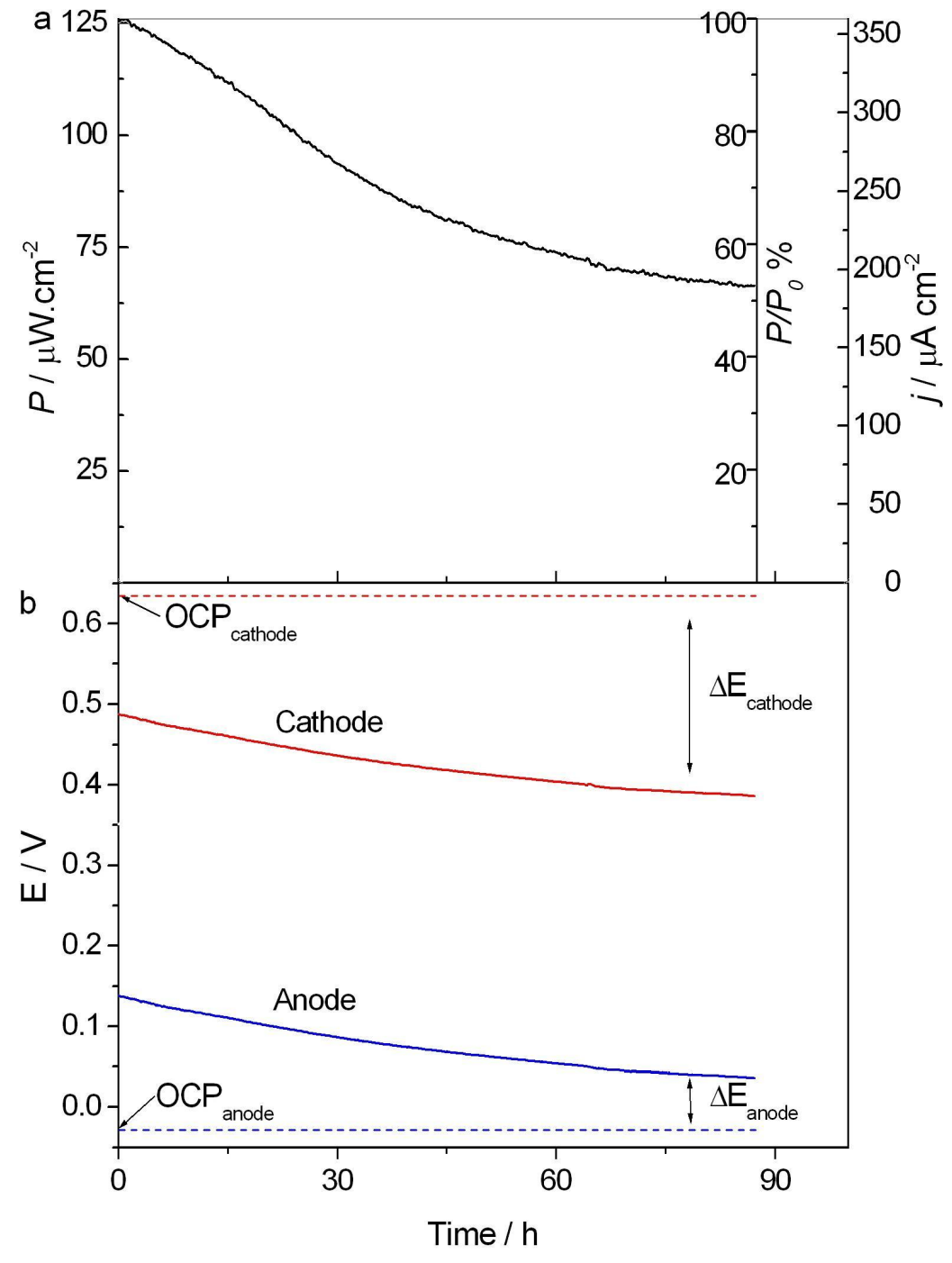

Figure_5 


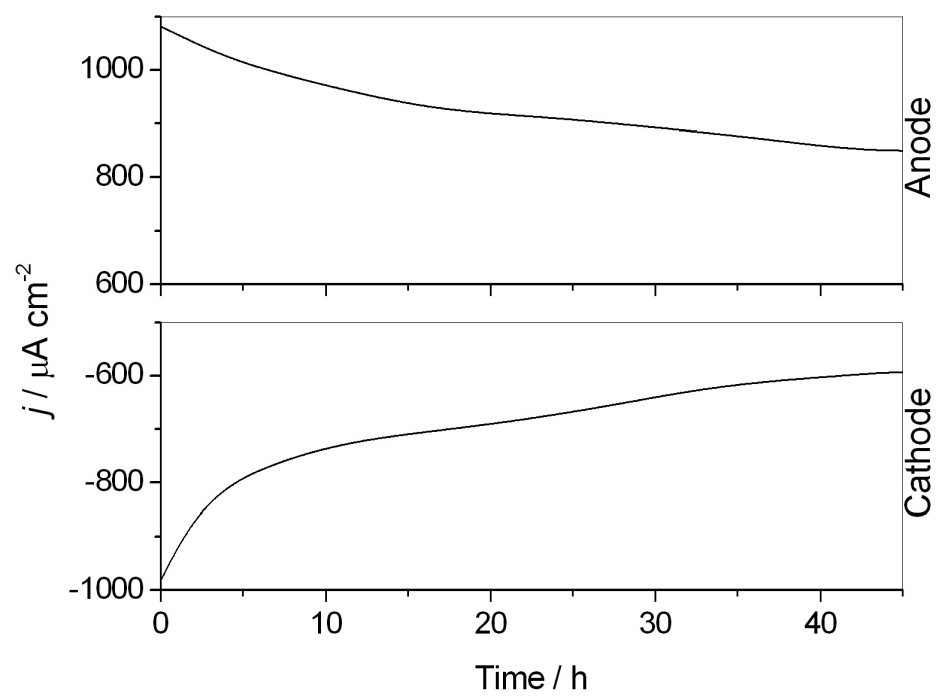

Figure_6 


\section{Supporting information}

\section{A one-compartment fructose/air biological fuel cell based on direct electron transfer}

Xuee $\mathrm{Wu}^{\mathrm{a}}$ Feng Zhao ${ }^{\mathrm{a}}$, John R. Varcoe ${ }^{\mathrm{a}}$, Alfred E. Thumser ${ }^{\mathrm{b}}$, Claudio Avignone-Rossa ${ }^{\mathrm{c}}$, Robert C.T. Slade ${ }^{\mathrm{a}}$

${ }^{a}$ Chemical Sciences, ${ }^{b}$ Biological Sciences, ${ }^{c}$ Microbial Sciences,

University of Surrey, Guildford, GU2 7XH, United Kingdom

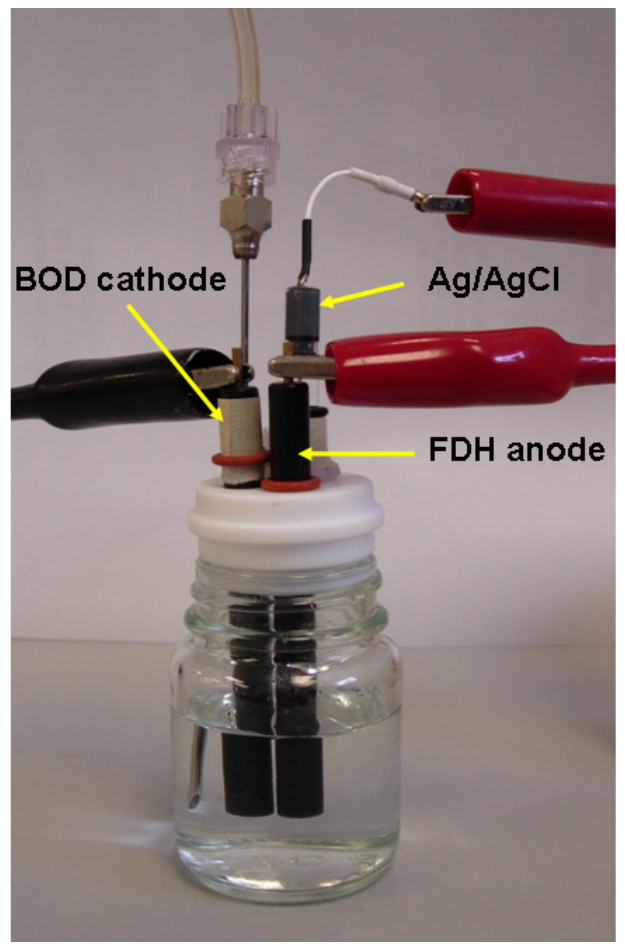

Scheme 1 The configuration of the one-compartment BFC. 
Table 1. Summary of one-compartment enzymatic fuel cells based on direct electron transfer

\begin{tabular}{|c|c|c|c|c|c|}
\hline $\begin{array}{l}\text { System } \\
\text { (Oxidation/reduction) }\end{array}$ & $\begin{array}{l}\text { Anode } \\
\text { enzyme }\end{array}$ & $\begin{array}{l}\text { Cathode } \\
\text { enzyme }\end{array}$ & $\begin{array}{l}\text { Open } \\
\text { circuit } \\
\text { voltage } \\
\text { /V }\end{array}$ & $\begin{array}{l}\text { Power } \\
\text { output } \\
/ \mu \mathrm{Wcm}^{-2}\end{array}$ & $\begin{array}{l}\text { Operation } \\
\text { Half-life } \\
\text { /h }\end{array}$ \\
\hline $\begin{array}{l}\text { Ethanol-ethanol } \\
\text { (Ramanavicius et al., } \\
\text { 2008) }\end{array}$ & $\begin{array}{l}\text { Quino- } \\
\text { hemoprotein- } \\
\text { alcohol } \\
\text { dehydrogenase }\end{array}$ & $\begin{array}{l}\text { Alcohol } \\
\text { dehydrogenase- } \\
\text { microperoxidase }\end{array}$ & 0.24 & 1.5 & 26 \\
\hline $\begin{array}{l}\text { Ethanol-glucose } \\
\text { (Ramanavicius et al., } \\
\text { 2005) }\end{array}$ & $\begin{array}{l}\text { Alcohol } \\
\text { dehydrogenase }\end{array}$ & $\begin{array}{l}\text { Glucose oxidase } \\
\text { microperoxidase }\end{array}$ & 0.27 & 0.2 & 60 \\
\hline $\begin{array}{l}\text { Fructose- } \mathrm{O}_{2} \\
\text { (Kamitaka, et al., 2007) }\end{array}$ & $\begin{array}{l}\text { Fructose } \\
\text { dehydrogenase }\end{array}$ & Laccase & 0.79 & 850 & $>12$ \\
\hline $\begin{array}{l}\text { Glucose- }-\mathrm{O}_{2} \\
\text { (Coman, et al., 2008) }\end{array}$ & $\begin{array}{l}\text { Cellobiose } \\
\text { dehydrogenase }\end{array}$ & Laccase & 0.73 & $>5$ & $>38$ \\
\hline $\begin{array}{l}\mathrm{H}_{2}-\mathrm{O}_{2} \\
\text { (Vincent, et al., 2005) }\end{array}$ & Hydrogenase & Laccase & 0.97 & 5 & $>0.25$ \\
\hline $\begin{array}{l}\mathrm{H}_{2} \text {-air } \\
\text { (Vincent, et al., 2006) }\end{array}$ & Hydrogenase & Laccase & 0.95 & 5.2 & $>24$ \\
\hline $\begin{array}{l}\text { glucose-air } \\
\text { (Wang et al. 2009) }\end{array}$ & glucose oxidase & laccase & $\sim 0.5$ & 1.38 & 12 \\
\hline $\begin{array}{l}\text { Fructose-air } \\
\text { (Present work) }\end{array}$ & $\begin{array}{l}\text { Fructose } \\
\text { dehydrogenase }\end{array}$ & $\begin{array}{l}\text { Bilirubin } \\
\text { oxidase }\end{array}$ & 0.63 & 126 & $>87$ \\
\hline
\end{tabular}

\section{References}

Coman,V., Vaz-Dominguez, C., Ludwig, R., Herreither, W., Haltrich, D., De Lacey, A.L., Ruzgas, T., Gorton, L., Shleev, S., 2008, Phys. Chem. Chem. Phys. 10, 6093-6096.

Kamitaka, Y., Tsujimura, S., Setoyama, N., Kajino, T., Kano, K., 2007, Phys. Chem. Chem. Phys. 9, 1793-1801.

Ramanavicius, A., Kausaite, A., Ramanaviciene, A., 2005, Biosens. Bioelectron. 20, $1962-$ 1967.

Ramanavicius, A., Kausaite, A., Ramanaviciene, A., 2008, Biosens. Bioelectron. 24, 761766.

Vincent, K. A., Cracknell, J.A., Lenz, O., Zebger, I., Friedrich B., Armstrong, F.A., 2005, Proc. Nat. Acad. Sci. USA 102, 16951-16954.

Vincent, K. A., Cracknell, J.A., Clark; J.R., Ludwig, M., Lenz, O., Friedrich B., Armstrong, F.A., 2006, Chem. Commun., 5033-5035.

Wang, S.C., Yang, F., Silva, M., Zarow, A., Wang, Y., Iqbal, Z. 2009, Electrochem. Commun. 11, 34-37. 